\title{
REDUCTION OF POLLUTION EMISSION BY USING SOLAR ENERGY IN EASTERN POLAND
}

\author{
Piotr Dragan', Agata Zdyb' \\ 1 Faculty of Environmental Engineering, Lublin University of Technology, Nadbystrzycka 40B, 20-618 Lublin, \\ Poland, e-mail: a.zdyb@pollub.pl
}

Received: 2017.05.05

Accepted: 2017.06.01

Published: 2017.07.01

\begin{abstract}
The present work is devoted to the analysis of electric energy production in photovoltaic power plant located in eastern part of Poland and to the estimation of pollution avoided due to the use of solar radiation energy. Photovoltaic power plant consists mainly of silicon polycrystalline modules but in its experimental part thin film modules of three different technologies are also installed giving the total power of 1.4 MWp. In 2015 the PV plant produced above 1.5 MWh of electric energy. Benefits of renewable energy use result in a significant reduction of emissions that are harmful to people and other living species too.
\end{abstract}

Keywords: photovoltaic plant, coal combustion, pollution emission

\section{INTORDUCTION}

The development of industrial societies and the urbanization of the third world countries, including an increase in the population by 2 billion, that is $45 \%$, have increased the demand for our civilization on effecting power by $6 \mathrm{TW}$, that is by $63 \%$ over the past $20-30$ years. Despite a considerable development in the field of renewable energy sources, fossil fuels such as hard coal, oil and natural gas are still used extensively. At present, $85 \%$ of the energy demand in the world is covered by the use of fossil fuels, including around $65 \%$ of the energy demand in Poland that is covered by coal, $22 \%$ - oil and $12 \%$ - natural gas. The amount of the most commonly used fuels with different calorific values and the estimated time they will be sufficient at the present consumption level are shown in Table 1.

The side effect of burning traditional fossil fuels is the release of oxides of carbon, sulfur and nitrogen, and also dust that is a carrier of toxic compounds, such as polycyclic aromatic hydrocarbons (PAHs), cadmium and lead [Flagan and Seinfeld 1988, Figueroaa et al. 2008] into the atmosphere. These compounds can cause respiratory diseases and skin and eye irritation $\left(\mathrm{NO}_{x}, \mathrm{SO}_{x}\right.$, dust), neurological disorders $(\mathrm{Hg}, \mathrm{Pb})$ as well as mutagenic effects (PAHs, cadmium). In addition to the direct threat to living organisms, carbon dioxide included to the emitted substances, together with water vapor, methane, freon and nitrous oxide, forms a group of the so-called greenhouse gases [Caldeira et al. 2003, Hoffert et al. 1998, Kessel 2000] that are recognized as one of the causes of global warming. In general, the anthropogenic emission of pollutants, though in total it is lower than natural one caused by volcanic eruptions, storms and fires, has serious consequences for human health and life because it occurs primarily in inhabited areas.

The improvement of the air condition is influenced by the use of various waste gas treatment technologies, and in the case of coal, which is Poland's most popular fuel used in power plants and combined heat and power plants, the development and implementation of clean coal technologies is of particular importance. These types of technologies can be used in the extraction and enrichment stages of the raw material as well as in the combustion and exhaust purification process. Such solutions include, for example, coal gasification, the use of fluidized boilers, oxygenenriched combustion, as well as exhaust purifica- 
Table 1. The world fossil fuels reserves [World Energy Outlook, 2014]

\begin{tabular}{|l|c|c|c|c|}
\hline \multicolumn{1}{|c|}{ Raw material } & $\begin{array}{c}\text { Resources } \\
{[\text { million tons] }}\end{array}$ & $\begin{array}{c}\text { Resource structure } \\
{[\%]}\end{array}$ & $\begin{array}{c}\text { Resource availability } \\
{[\text { years] }}\end{array}$ & Calorific value \\
\hline Carbon & 469298 & 59.6 & 158 & $17-31[\mathrm{MJ} / \mathrm{kg}]$ \\
\hline Petroleum & 159644 & 20.3 & 41 & $41-49[\mathrm{MJ} / \mathrm{kg}]$ \\
\hline Natural gas & 158815 & 20.1 & 63 & $35.5\left[\mathrm{MJ} / \mathrm{m}^{3}\right]$ \\
\hline Total & 787757 & 100 & 84 & - \\
\hline
\end{tabular}

tion processes aiming at desulfurization, dedusting and reduction of nitrogen oxides. Sequestration techniques may be used to reduce $\mathrm{CO}_{2}$ levels in the atmosphere.

Increasing energy demand, limited fossil fuel resources, and harmful emissions from their combustion have led to the need to develop new, environmentally friendly energy sources. This issue is reflected in the legislation adopted for many years at European Union and national and regional levels. In 2009, Directive 2009/28/EC on the promotion of the use of energy from renewable sources was announced, which resulted in the adoption of the National Action Plan on Renewable Energy Sources in Poland in 2010, supplemented in 2011. Two years later, the European Parliament resolution of 21 May 2013 on current challenges and opportunities for renewable energy in the European internal energy market was announced. In our country, in March 2015, Act on Renewable Energy Sources was adopted which provided stable legislative conditions and tariffs guaranteed for prosumer installations.

Among the various renewable energy sources, solar power is particularly promising because of its widespread availability and unlimited resources. The most common ways of using this energy are the use of solar collectors and photovoltaic modules.

In this paper, we present a case study of photovoltaic technology in a group of municipalities located in the eastern part of Poland. The production of electricity was combined with the set values of pollutants that would be emitted if traditional fuels were combusted. The analysis allowed for the assessment of the ecological benefits achieved in a given area through the use of solar energy.

\section{METHODS AND RESEARCH FACILITY}

Photovoltaic power plant discussed in this work is located in eastern part of Poland (latitude $51^{\circ} 51$, longitude $23^{\circ} 10$ ), and it was created as a result of cooperation of local governments from five boroughs. The geographical location of municipalities' partnership, characterized by outstanding solar conditions (1700 h of intense solar energy per year), causes that it has a great potential in this regard. Solar energy resources throughout the area of Poland, because of its location in the temperate climate zone, are characterized by uneven distribution in the annual cycle.

In the photovoltaic power plant with a capacity of 1.4 MWp that came into existence, solar energy is used to produce electricity in a gridconnected system, assuming the sale of energy to the electricity grid. In the farm a direct conversion of solar energy occurs - of the optical solar radiation - into electricity through photovoltaic conversion. For this purpose, photovoltaic cells connected together in series have been installed in order to obtain a desired voltage, and then in parallel to obtain the necessary power.

The investment involved the installation of 5560 of silicon polycrystalline modules (poly-Si) with a total capacity of $1.39 \mathrm{MWp}$. The efficiency of these modules is at least $15.3 \%$ at standard conditions including insolation of $1000 \mathrm{~W} / \mathrm{m}^{2}$ and a module temperature equal to $25^{\circ} \mathrm{C}$. Silicon polycrystalline modules represent the majority of all mounted modules. In the experimental part of the farm 104 thin film modules composed of amorphous silicon (a-Si), gallium-indium diselenide-copper (CIGS), and cadmium telluride (CdTe) have been also installed. The total power of the thin-film panels is equal to $10,44 \mathrm{kWp}$. Table 2 shows the number of modules and the power of each technology. The total area of the land on which the plant is located is 3.5 hectares.

One of the crucial elements of PV installations except the photovoltaic modules are inverters, that is devices supporting control and regulation system. They connect the solar panels to the electricity network. Their main task is to convert the direct current produced by the photovoltaic module, into the alternating current with the parameters of the grid. Thanks to these de- 
Table 2. The number of modules and the nominal power of each technology modules

\begin{tabular}{|c|c|c|c|}
\hline Modules technology & Number of modules & Nominal power of the module [Wp] & Installed power [kWp] \\
\hline $\mathrm{a}-\mathrm{Si}$ & 36 & 98 & 3.42 \\
\hline $\mathrm{CIGS}$ & 24 & 155 & 3.72 \\
\hline $\mathrm{CdTe}$ & 44 & 75 & 3.3 \\
\hline poly-Si & 5560 & 250 & 1390 \\
\hline
\end{tabular}

vices, all energy produced can be transferred into the network. On average, at each 80 photovoltaic modules one inverter was installed with the AC active power equal to $20 \mathrm{~kW}$ each, which results in 70 installed inverters on 5560 polycrystalline modules. These inverters have a maximum efficiency of not less than $98 \%$ and the efficiency of the Euro-eta not less than $97.5 \%$. For each type of thin-film modules, one inverter of active power $3.5 \mathrm{~kW} \mathrm{AC}$ has been installed. On this farm is thus 70 inverters of the $\mathrm{AC}$ power $20 \mathrm{~kW}$ and 3 inverters of the $\mathrm{AC}$ power $3.5 \mathrm{~kW}$.

Methodology of experimental research conducted in the present photovoltaic power plant is based on data recording, such as the amount of generated electricity, the temperature of the modules and insolation in the module plane. Recording of the operating parameters of the various photovoltaic modules types, i.e. silicon polycrystalline and thin-film a-Si, CdTe and CIGS technologies is performed by using procedures implemented in inverters for recording daily, monthly, and annual production of power and energy for each part of the installation separately. Measurement of the intensity of radiation is performed by means of pyranometer placed in the same location as the photovoltaic power station, in its central part. Ambient temperature measurement and the temperature of the modules is carried out using appropriately calibrated thermocouples. Readings of all the measured values: the amount of generated energy, solar radiation and the temperatures were recorded every 5 minutes.

\section{RESULTS}

Demand for electricity in public utilities and lighting in the discussed partner communities is 1434.5 MWh per year [Dragan and Lubańska 2016]. On the basis of the demand it is possible to estimate the required area of the modules, according to formula [Luque and Hegedus 2003]:

$$
S=\frac{Q}{F \eta H^{\prime}}
$$

where: $Q$ - annual demand [kWh/year],

$F$ - loses factor between module and receiver,

$\eta$ - module efficiency,

$H$ - annual irradiation $\left[\mathrm{kWh} / \mathrm{m}^{2}\right.$ year $]$.

In the photovoltaic power plant located in the described above location in eastern Poland, the area of installed modules is equal to $8753 \mathrm{~m}^{2}$ for the entire installation. Knowing the surface of the modules, the value of electricity produced by a given photovoltaic installation can be estimated from the dependence:

$$
E=0.85 H S \eta
$$

The theoretical energy output determined in accordance with the above formula is equal to $1,450 \mathrm{MWh}$, assuming average modules efficiency of $15 \%$ and irradiation in the module plane of $1300 \mathrm{kWh} / \mathrm{m}^{2}$ per year. Experimental data from 2015 show that the total electricity production in this photovoltaic power plant is equal to $1530.42 \mathrm{MWh}$. The amount of real energy produced is therefore higher than predicted, which can be caused by the favorable sunshine in a given calendar year and ambient temperatures or slight pollution of the modules. The main contribution to the power generation in the analyzed PV plant (99.26\%) are poly-Si modules that produced 1518.94 MWh. Thin-layer modules constituting an experimental part of a power plant produced $11.32 \mathrm{MWh}$, only $0.74 \%$ of the total energy sold to the grid. Table 3 shows energy production related to installed capacity of each kind of installation. In total, the energy produced by the photovoltaic power plant covers the needs of the partner municipalities for electricity in public utilities and for lighting.

In order to obtain $1530 \mathrm{MWh}$ of electricity by conventional means, 688 tons of coal would have to be used in the traditional coal-burning process, 
Table 3. Energy production related to installed capacity of each kind of installation

\begin{tabular}{|c|c|c|}
\hline Technology & Installed capacity $[\mathrm{kWp}]$ & Energy production in 2015 [KWh/kWp] \\
\hline $\mathrm{a}-\mathrm{Si}$ & 3.42 & 1031.89 \\
\hline $\mathrm{CIGS}$ & 3.72 & 1115.59 \\
\hline $\mathrm{CdTe}$ & 3.3 & 1058.58 \\
\hline poly-Si & 1390 & 1080.06 \\
\hline
\end{tabular}

assuming that on average $0.45 \mathrm{~kg}$ of coal is needed to produce $1 \mathrm{kWh}$ of energy. Burning of 688 tons of coal would involve the emission of many pollutants into the atmosphere.

The amount of harmful substances emitted to the atmosphere depends primarily on the type of fuel that is its calorific value, ash and sulfur content, and the methods used to purify the gases [www.iea.org]. The emission of a given substance can be determined using the formula:

$$
E=B \cdot W
$$

where: $E$-volume of emissions,

$B$ - fuel consumption,

$W$ - emission factor per unit of fuel consumed.

Calculated according to the Eq. (3) ammount of substances emitted during combustion of $688 \mathrm{t}$ of carbon are presented in Table 4. The content of sulfur in coal that ranges from $0.7 \%$ to $1.3 \%$ (eg. in Bogdanka coal mine) influences emmision of sulfur oxides. The emmision of dust depends on the coal quality, too. In our considerations we assumed the contenet of dust in coal in the range of $4-31 \%$. Depending on combustion technology the amounts of emited nitrogen and carbon oxides and pirene also differ.

The performance of the analzyed photovoltaic power plant differ significantly in summer and winter half of the year which is shown in Figure 1. The PV plant provides 1135.5 MWh in April to September period, and 394.92 MWh from October to March. Warm half of the year, in which $74 \%$ of the entire energy is produced, is significantly more profitable but energy demand for lightening is higher in colder part of the year. However, the excess of energy generated in sunny months are sold to the grid so they finally cover the electric energy demand.

Table 4. Emissions of pollution arising in combustion of $688 \mathrm{t}$ of coal

\begin{tabular}{|l|c|}
\hline \multicolumn{1}{|c|}{ Pollutant } & Emission amount [kg] \\
\hline $\mathrm{SO}_{\mathrm{x}} / \mathrm{SO}_{2}$ & $7705.6-14310.4$ \\
\hline $\mathrm{NO}_{\mathrm{x}} / \mathrm{NO}_{2}$ & $688-2201.6$ \\
\hline $\mathrm{CO}$ & $6880-48160$ \\
\hline $\mathrm{CO}$ & $1272800-1465440$ \\
\hline Dust TSP & $2752-42656$ \\
\hline Benzopyrene & $2.201-9.632$ \\
\hline
\end{tabular}

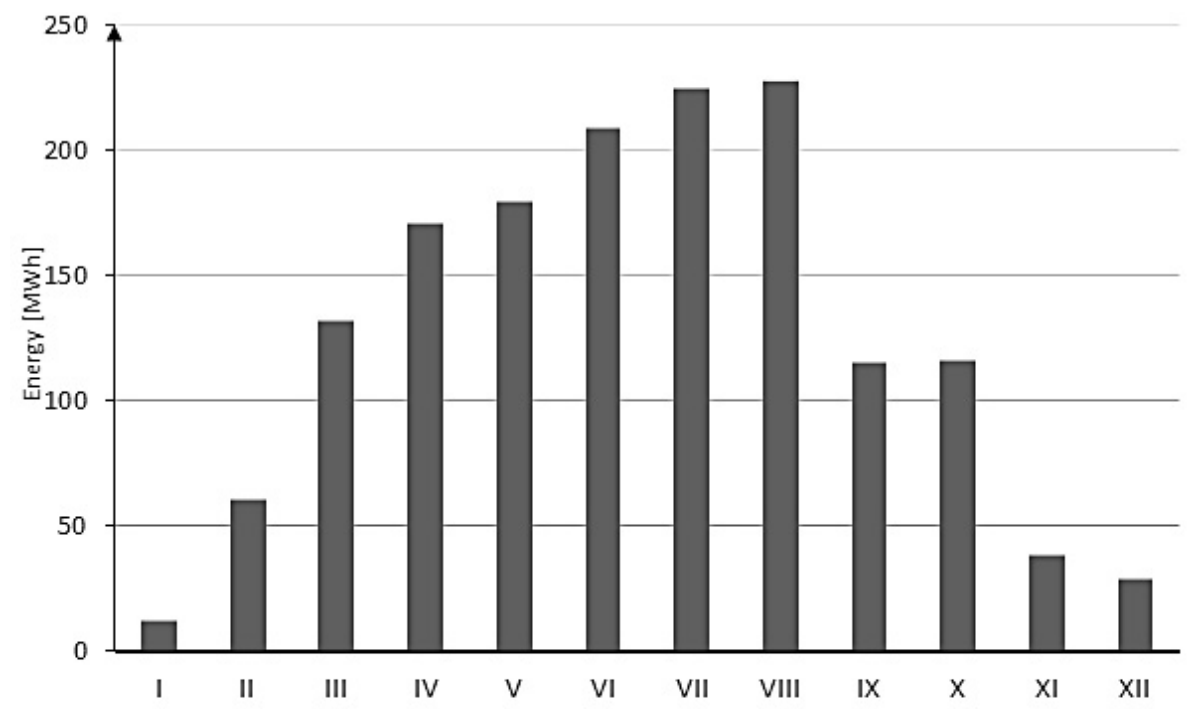

Fig. 1. The performance of the PV plant in 2015 


\section{CONCLUSIONS}

The photovoltaic power plant located in eastern Poland produces $1530.42 \mathrm{MWh}$ of electricity annually. This amount of energy covers the needs of partner municipalities for public utilities and lighting. In a conventional power station, the production of this amount of energy would involve burning of 688 tons of carbon and consequently emitting significant amounts of sulfur, nitrogen and carbon oxides, as well as benzopyrene and dust. Using solar energy in photovoltaic conversion and thus replacing carbon with a clean source of energy will reduce the emission of harmful substances into the atmosphere. It should also be taken into account that apart from the emissions generated by the coal combustion process, additional contamination arises during the exploitation of the raw material and during transport.

The reduction of pollutant emissions that has been achieved in municipalities using a photovoltaic power plant contributes to the improvement of the quality of the environment both in the areas inhabited by humans and in nature reserves. Therefore, not only people but also other living organisms experience beneficial effects. It is therefore advisable to develop a low-carbon economy, which should include the diversification of energy sources, the improvement of energy production efficiency, and education aimed at raising the ecological awareness.

\section{REFERENCES}

1. Caldeira K., Jain A.K., Hoffert M.I. 2003. Climate sensitivity uncertainty and the need for energy without CO2 emission. Science, 299, 2052-2054.

2. Dragan P., Lubańska Z. 2016. The Energy Efficiency of Polycrystalline and Thin Film Photovoltaic Farm in the Dolina Zielawy. Ecological Engineering, 50, 42-48.

3. Figueroaa J.D., Fouta T., Plasynskia S., McIlvriedb H., Srivastavab R.D 2008. Advances in CO2 capture technology-The U.S. Department of Energy's Carbon Sequestration Program. International Journal of Greenhouse Gas Control, 2, 9-20.

4. Flagan R.C., Seinfeld J.H. 1988. Fundamentals of Air Pollution Engineering, Prentice Hall, New Yersay.

5. Hoffert M.I., Caldeira K., Jain A.K., Haites E.F., Harvey L.D.D., Potter S.D., Schlesinger M.E., Schneider S.H., Watts R.G., Wigley T.M.L., Wuebbles J. 1998. Energy implications of future stabilization of atmospheric CO2 content. Nature, 395, 881-884.

6. Kessel D.G. 2000. Global warming - facts, assessment, countermeasures. Journal of Petroleum Science and Engineering, 26, 157-168.

7. Luque A., Hegedus S. 2003. Handbook of Photovoltaic Science and Engineering. Wiley, Chichester.

8. World Energy Outlook, 2014. International Energy Agency, Paris.

9. http://www.iea.org/topics/coal/ (04.05.2017) 